\title{
Biological Resistance of Eucalyptus Wood Treated with Chromated Copper Borate to Fungi Decay
}

\author{
Pedro Augusto Fonseca Lima ${ }^{1}$ (1) \\ Carlos Roberto Sette $\mathrm{Jr}^{1}$ (D) \\ Anna Sofya Vanessa Silvério da Silva ${ }^{2}$ \\ José Roberto Victor de Oliveira ${ }^{2}$ (1) \\ Marcelo Fontana da Silveira ${ }^{2}$ (1) \\ Fernando Nunes Gouveia ${ }^{2}$
}

\begin{abstract}
The objective of this study was to evaluate the efficiency of a preservative treatment with Chromated Copper Borate (CCB) in different concentrations and autoclave pressure time on the biological resistance of Eucalyptus urophylla $\mathrm{x}$ Eucalyptus grandis (called urograndis). Urograndis fence posts were submitted to industrial autoclaving in nine treatments as a function of CCB concentration and pressure time: 1.5\% (30, 60 and 90 minutes); 2.0\% (30, 60 and 90 minutes); and $2.5 \%$ (30, 60 and 90 minutes). Then the obtained specimens were submitted to an accelerated laboratory decay test. The industrial preservative treatment increased the resistance of the wood to decay and the concentration of $1.5 \%$ CCB and 30 minutes of autoclave pressure can be applied to treat urograndis wood without compromising its resistance to the attack of white-rot and brown-rot fungi.
\end{abstract}

Keywords: Accelerated decay test, $\mathrm{CCB}$ concentration, autoclave pressure time.

\section{INTRODUCTION}

Species of the Eucalyptus genus are used in supplying raw material for various industrial segments such as cellulose and paper, energy, and solid products such as lumber and fence posts. In the year 2017, an area of 313.60 thousand hectares of planted forests was destined to serve the solid wood market (INDÚSTRIA BRASILEIRA DE ÁRVORES - IBÁ, 2018), with emphasis on Eucalyptus fence posts, which are used in civil and rural construction projects.

Eucalyptus' wood used in civil and rural construction, especially in ground contact as fence posts, presents low natural durability (Oliveira et al., 2017) due to its anatomical and chemical characteristics (Oliveira et al., 2012). Knowledge of the natural resistance of wood to attack by xylophagous organisms is important for recommending the most appropriate use, reducing unnecessary expenses on replacing parts and decreasing the impacts on the environment (Paes et al., 2013).

In this sense, a set of measures and procedures must be implemented in using wood as fence posts or in another use in contact with the soil, such as industrial preservative processes (Valle et al., 2013) to increase resistance to wood decay xylophagous organisms (Vidal et al., 2015), especially regarding rotting fungi, which are the main cause for wood damage, causing devaluation and reducing the service life of the product (Kelley et al., 2002; Vivian et al., 2015; Lopes et al., 2017).

Among the preservatives used in industrial processes in Brazil, water-soluble substances such as Chromated Copper Arsenate (CCA) and Chromated Copper Borate (CCB) stand out. Although CCA is the most widely used product in Brazil (Vidal et al., 2015), its use in wood impregnation can cause health damage due to exposure to arsenic, and therefore the use of CCB can not only reduce environmental risks, but also health problems, since boron is less toxic compared to arsenic (Gallio et al., 2017).

Some factors involved in the process and the preservative product influence the final quality of treated fence posts, such as temperature (oil-soluble), pressure time and concentration of the preservative product (Vivian et al., 2012; Gallio et al., 2017).

${ }^{1}$ Universidade Federal de Goiás, Setor de Engenharia Florestal, Goiânia, GO, Brasil.

${ }^{2}$ Serviço Florestal Brasileiro, Laboratório de Produtos Florestais, Brasília, DF, Brasil. 
The most common industrial process for wood treatment in Brazil employs $60 \mathrm{~min}$ as pressure time and $2.0 \%$ product concentration (Valle et al., 2013; Amaral et al., 2014; Lopes et al., 2017; Gallio et al., 2017). However, with the high cost of preservative coupled with the rotation time of wood pieces inside the autoclave, it is essential to evaluate alternative times and concentrations that provide better autoclaving conditions aiming at lower costs in producing treated wood.

The accelerated laboratory decay test with white, brown and soft rot fungi are one of the main techniques for assessing wood resistance to attacks by xylophagous organisms and can be considered the first stage to determine the efficiency of wood preservatives (Ramos et al., 2006; Paes et al., 2007; Vivian et al., 2015). The objective of this study was to evaluate the efficiency of preservative treatments with CCB at different concentrations and pressure times in the biological resistance of Eucalyptus urophylla $\mathrm{x}$ Eucalyptus grandis wood subjected to white-rot and brown-rot fungi under controlled conditions.

\section{MATERIAL AND METHODS}

\subsection{Sample collection, preparation and preservative process}

Ten Eucalyptus urophylla S.T. Blake x Eucalyptus grandis W. Mill ex Maiden hybrid (called urograndis) trees were selected at seven years old from a plantation located in the municipality of Nerópolis ( $16^{\circ} 18^{\prime} 28.85^{\prime \prime} \mathrm{S}$ and $\left.49^{\circ} 13^{\prime} 3.80^{\prime \prime} \mathrm{W}\right)$ in the state of Goiás, Brazil. The trees were cut down, debarked and obtained wood logs along the trunk, with a length of 2.20 meters, and denominated fence posts. Four logs were cut per tree, totaling 40 round pieces.

The urograndis fence posts were dried for 60 days until reaching $20 \%$ humidity, and were divided into two groups: the treated and untreated. Four fence posts were selected in their original state for the untreated group (or control specimens), without receiving preservative treatment.

The fence posts in the treated group were submitted to the industrial preservative treatment with Chromated Copper Borate (CCB) (MOQ OX 50, Montana Química, SA) with $50 \%$ of active ingredients in an autoclave of 15 meters in length and 1.60 meters diameter.

Full-cell process (Bethell method) was applied, with an initial vacuum of $600 \mathrm{mmHg}$ for $30 \mathrm{~min}$, and $12 \mathrm{kgf} \mathrm{cm}^{-2}$ of pressure; and a final vacuum of $600 \mathrm{mmHg}$ for 15 minutes at concentrations of $1.5 ; 2.0$ and $2.5 \%$, and pressure times of 30 ; 60 and $90 \mathrm{~min}$, totaling nine treatments ( 3 concentrations $\mathrm{x}$ 3 pressure times; four fence posts per treatment).

The concentrations and pressure times used in this study were defined as within the commonly used parameters in wood treatment plants in Brazil (Amaral et al., 2014; Gallio et al., 2017; Lopes et al., 2017). The fence posts were dried for 30 days after the preservative process at the different concentrations and times for the fixation of the product used in the impregnation.

\subsection{Accelerated laboratory decay test}

The accelerated decay test was conducted at the Wood Biodegradation and Preservation Laboratory (Laboratório de Biodegradação e Preservação da Madeira), of the Forest Products Laboratory (Laboratório de Produtos Florestais - LPF), located in Brasília, Brazil, according to the American Society for Testing and Materials - ASTM D- 2017 (2005) and ASTM D-1413 (2007).

The test preparation included fungi cultivation, preparing the soil samples and flasks for developing the culture in an aseptic environment, as well as evaluating the mass loss caused by the tested fungi.

\subsubsection{Fungi cultivation}

Two fungi were used for this experiment: white-rot Trametes versicolor (L.) Lloyd (mad 697), and brown-rot Gloeophyllum trabeum (Pers.) Murrill (mad 617), from the $L P F$ fungus collection. The culture medium used for fungi growth was prepared with deionized water and malt extract (30g of the extract/ $1000 \mathrm{ml}$ of water). The solution was sterilized in an autoclave at $121^{\circ} \mathrm{C}$ with a pressure of $1 \mathrm{kgf} \mathrm{cm}^{-2}$ for 30 minutes and then maintained in the incubator at $27^{\circ} \mathrm{C}$ and $70 \%$ relative humidity for seven days to verify the occurrence of contamination.

The fungi were harvested aseptically in a laminar flow hood after ultraviolet light action for $5 \mathrm{~min}$. Inoculates of approximately $1 \mathrm{~cm}^{2}$ containing mycelia, were added to the culture medium and routed to a shaker table at $100 \mathrm{rpm}$ for $72 \mathrm{~h}$. The fungi then remained in the incubator for four weeks until their full development.

\subsubsection{Sample preparation}

Wood specimens from the fence posts sapwood region were obtained, in dimensions $2.0 \times 2.0 \times 1.0 \mathrm{~cm}$ (radial x tangential $\mathrm{x}$ longitudinal). Forty specimens were collected from each conditions (nine treated: three concentrations $\mathrm{x}$ three pressure times and one untreated); twenty for exposure to the Gloeophyllum trabeum fungus, and twenty for Trametes versicolor, totaling 400 wood specimens.

The specimens were sanded to remove burrs and small barbs and placed in an oven at $50^{\circ} \mathrm{C}\left( \pm 2^{\circ} \mathrm{C}\right)$, with forced 
ventilation until reaching constant mass. This procedure was performed on an electronic scale with an accuracy of $0.0001 \mathrm{~g}$. At the end of this step, the initial mass of the specimens was registered and then used to calculate the mass loss.

\subsubsection{Soil and flask preparation}

Soil preparation and flasks were conducted according to ASTM D 1413 (2007) using glass vials with a screw cap of $250 \mathrm{~mL}$ capacity. Next, $130 \mathrm{~g}$ of red latosol (horizon B) was added to each flask from the Fazenda Água Limpa of the Universidade de Brasília (UnB), Brazil. This soil was sieved in a $30 \mathrm{~mm}$ aperture mesh, its $\mathrm{pH}$ was corrected to $6 \pm 0.5$, and $65 \mathrm{~mL}$ of distilled water was added to each flask to achieve the water retention capacity and soil moisture content established in the standard.

Next, a wooden plate $(3 \times 29 \times 35 \mathrm{~mm})$ was laid on the soil to support the mycelial development in each vial. Pinus (Pinus spp.) was used in flasks inoculated with brown rot fungus, and Embaúba (Cecropia spp.) was used in flasks with white-rot fungi. After receiving the plates, the vials were autoclaved at $120^{\circ} \mathrm{C}$ for 45 minutes and taken to an incubator (RH $75 \pm 2 \%$ and $25 \pm 2{ }^{\circ} \mathrm{C}$ ) for 10 days to check for possible contamination.

\subsubsection{Fungi inoculation}

The culture media with each of the already developed rotting fungi were aseptically homogenized from an adaptation of ASTM D 2017 (2005) and ASTM D 1413 (2007) in a blender, and then $3 \mathrm{ml}$ of this solution were inoculated into the support board and soil with an automatic pipette. The flasks were returned to the incubator for four weeks, the time required for the fungi properly develop on the carrier plate. After this period, the samples were sterilized under the already mentioned conditions, and after being naturally cooled were placed on the support plate colonized by the fungus. The vials were then returned to the incubator where they remained for up to 16 weeks.

\subsubsection{Evaluation of mass loss}

After the exposure period to the fungi in the incubator, the specimens were removed from the vials. The adhered mycelium was removed with a toothbrush with soft bristles. The wood specimens were taken to a greenhouse and kept under the already described conditions, where they remained until reaching constant mass and their final mass was registered.
The conditions (nine treated: three concentrations $x$ three pressure times and one untreated) proposed in this study were evaluated for the mass loss variation after the accelerated rotting test, calculated by the difference between the initial mass (before the fungal attack) and the final mass (after the fungal attack). The conditions were classified according to the average mass loss of the wood specimens, according to ASTM D 2017 (2005) (Table 1).

Table 1. Resistance classes of wood to fungi rot.

\begin{tabular}{lcc|}
\multicolumn{1}{c}{ Resistance class } & Mass loss (\%) & Residual mass (\%) \\
\hline Highly resistant (HR) & $0-10$ & $90-100$ \\
Resistant (R) & $11-24$ & $76-89$ \\
Moderately resistant (MR) & $25-44$ & $56-75$ \\
Non-resistant (NR) & $>45$ & $>55$
\end{tabular}

Source: ASTM D 2017 (2005)

The data distribution by the Shapiro-Wilk test, outliers by the Box-plot method, and the heterogeneity of the variance by the Bartlett and Levene tests ( $\mathrm{p}<0.05$ ) were performed. The data presented distribution normality and homogeneity of variance, and Analysis of Variance (ANOVA) and Tukey test $(p<0.05)$ was applied to verify the condition effect (treated and untreated), CCB concentration, autoclave pressure time and interactions.

\section{RESULTS AND DISCUSSION}

The analysis of variance indicated a significant effect of the condition (treated and untreated) on the mass loss of urograndis wood (Table 2). The preservative treatment with CCB increased the wood's resistance to the fungi attack.

Some studies have also found a higher resistance of wood to degrading agents when submitted to preservative treatment, evidencing lower mass loss when treated in controlled laboratory trials (Lazarotto et al., 2016; Lopes et al., 2017; Xuan et al., 2017).

There were no significant differences between concentrations (1.5 to $2.5 \%$ ), regardless of the type of rot (Table 2). The reduced mass loss with the $1 \%$ increase in the concentration of the CCB product applied to the fence posts was only $0.14 \%$ for Gloeophyllum trabeum and $0.41 \%$ for Trametes versicolor, indicating that the concentration of $1.5 \%$ can be applied to impregnate urograndis wood by autoclaving, without compromising its resistance to attack by white and brown rot fungi.

When evaluating the mass loss of wood treated at different concentrations (2.0, 4.0 and $6.0 \%)$ of CCB subjected to fungal deterioration, Gallio et al. (2017) also found satisfactory values for all concentrations, including the lowest used (2\%) with a mass loss of $1.23 \%$. 
Table 2. Wood mass loss in the presence of Gloeophyllum trabeum (GT) and Trametes versicolor (TV) by condition and CCB concentration.

\begin{tabular}{ccccccc} 
Condition & Concentration (\%) & $\begin{array}{c}\text { Mass loss } \\
\text { GT (\%) }\end{array}$ & Resistance class & $\begin{array}{c}\text { Mass loss } \\
\text { TV (\%) }\end{array}$ & Resistance class \\
\multirow{2}{*}{ Treated } & 1.5 & $0.81(0.24) \mathrm{a}$ & HR & $1.41(0.63) \mathrm{a}$ & HR \\
& 2.0 & $0.74(0.18) \mathrm{a}$ & HR & $1.10(0.25) \mathrm{a}$ & HR & HR \\
Untreated & 2.5 & $0.67(0.19) \mathrm{a}$ & HR & $1.00(0.25) \mathrm{a}$ & $\mathrm{NR}$ \\
\hline
\end{tabular}

The averages are followed by the standard deviation. Means followed by the same letter in the column do not differ statistically.

Evaluating the degree of resistance of urograndis wood according to ASTM D 2017 (2005), it was possible to determine that all the concentrations reached the minimum required to classify them as highly resistant, meaning that the mass loss of wood was less than $10 \%$. It is evidenced that the lower concentration used (1.5\%) gave the urograndis wood high resistance, with a residual mass of 99.2\% - 98.6\% for Gloeophyllum trabeum and Trametes versicolor, respectively.

Trametes versicolor caused the greatest mass losses: the wood untreated samples submitted to this fungus showed a reduction of more than $50 \%$ of their mass and were classified as non-resistant. On the other hand, the wood samples from the untreated fence posts were classified as resistant to the mass loss caused by Gloeophyllum trabeum.

The higher mass loss caused by the action of the Trametes versicolor fungus can be explained since white-rot fungi develop better in hardwoods (such as eucalyptus), while brown-rot fungi develop more in conifers (Vivian et al., 2015). White-rot fungi attack cellulose, hemicellulose and lignin, while brown-rot fungi only attack cellulose and hemicellulose, leaving lignin intact (Lelis et al., 2011).

The mean mass loss of the treated wood at different times (30,60 and $90 \mathrm{~min})$ and without the preservative treatment during the accelerated rotting test with the white-rot and brown-rot fungi are shown in Table 3.

Significant differences were verified between the times (30 to 90 minutes) for both types of rot. There was a reduction in the mass loss with a 60 minute pressure increase of the preservative treatment in $0.39 \%$ for Gloeophyllum trabeum and $0.57 \%$ for Trametes versicolor.

For the urograndis wood treatment by autoclaving, the results obtained in this study suggest that despite having the largest mass loss, the 30 minute condition does not compromise the wood's resistance to the white and brown-rot fungi attack. Scientific papers, which have evaluated the wood mass loss, treated with CCB by rot fungi in laboratory tests considering different pressure times are scarce, making it difficult to compare the data obtained in these studies.

In Figure 1 it is possible to observe the interaction between the $\mathrm{CCB}$ concentration and the autoclave pressure time in the mass loss of urograndis wood subjected to the accelerated rotting test in the presence of Gloeophyllum trabeum. Higher mass losses are associated with lower autoclave pressure times and lower CCB concentrations, although they are not always significant (Tables 2 and 3 ).

Higher mass losses were observed at all concentrations where the pressure in the autoclave was applied for 30 minutes (1.05, 0.94 , and $0.83 \%$ to $1.5,2.0$, and $2.5 \%$ respectively), while lower losses were found for all pressure time concentrations of 90 minutes $(0.60,0.59$, and $0.47 \%$ for $1.5,2.0$ and $2.5 \%$, respectively).

Despite the higher percentages of mass loss found in the conditions under which the wood was subjected for less time and with lower concentrations, all the woods exposed to Gloeophyllum trabeum are classified as highly resistant according to ASTM D 2017 (2005), as previously discussed.

For urograndis wood exposed to Trametes versicolor in the accelerated decay test (Figure 2), the mean mass loss varied from $0.93 \%$ ( $2.5 \%$ to 90 minutes) to $2.19 \%$ ( $1,5 \%$ to 30 minutes). This result shows the same behavior as that observed for brown-rot fungus, but with a lower mass loss difference in the concentrations of $2.0-2.5 \%$ and in the pressure times of 60-90 min. Despite the differences noted in the mass loss percentages, all applied conditions gave high resistance to urograndis wood in the presence of Trametes versicolor fungus.

Table 3. Wood mass loss in the presence of Gloeophyllum trabeum (GT) and Trametes versicolor (TV) by condition and autoclave pressure time.

\begin{tabular}{ccccccc} 
Condition & Time (minutes) & $\begin{array}{c}\text { Mass loss } \\
\text { GT (\%) }\end{array}$ & Resistance class & $\begin{array}{c}\text { Mass loss } \\
\text { TV (\%) }\end{array}$ & Resistance class \\
\multirow{2}{*}{ Treated } & 30 & $0.94(0.21) \mathrm{a}$ & $\mathrm{HR}$ & $1.54(0.48) \mathrm{a}$ & $\mathrm{HR}$ \\
& 60 & $0.72(0.16) \mathrm{ab}$ & $\mathrm{HR}$ & $0.99(0.25) \mathrm{b}$ & $\mathrm{HR}$ \\
Untreated & 90 & $0.55(0.18) \mathrm{b}$ & $\mathrm{HR}$ & $0.97(0.25) \mathrm{b}$ & $\mathrm{HR}$ \\
\hline
\end{tabular}

The averages are followed by the standard deviation. Means followed by the same letter in the column do not differ statistically. 

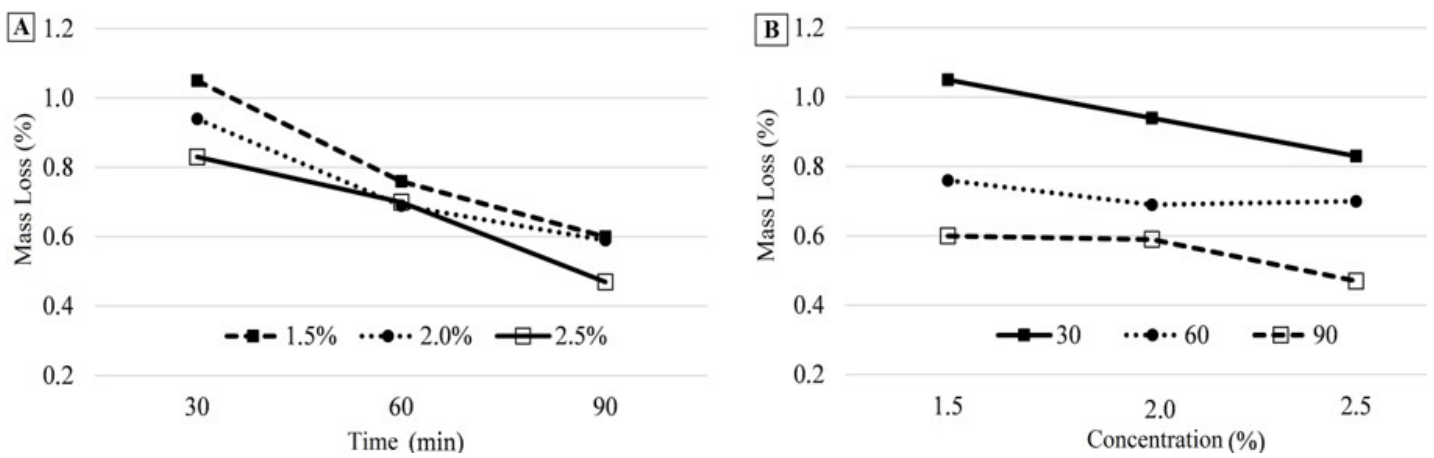

Figure 1. Interaction between time (A) and CCB concentration (B) in the urograndis wood mass loss in the presence of Gloeophyllum trabeum.
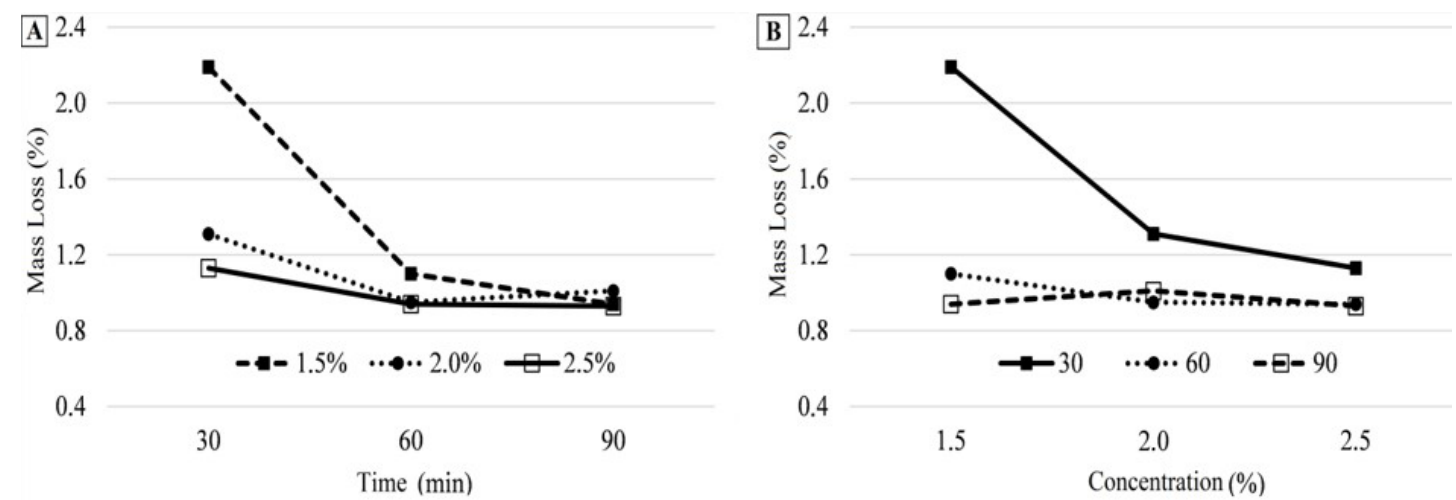

Figure 2. Interaction between time (A) and CCB concentration (B) in the urograndis wood mass loss in the presence of Trametes versicolor.

The results obtained in this study show that the application of CCB increases the resistance of urograndis wood to deterioration by fungi. Supplementary studies, such as the exposure of CCB treated wood in a field test in ground and the evaluation of boron leaching, as well the economic feasibility, are recommended for the recommendation of replacing Chromated Copper Arsenate (CCA) by CCB in the wood treatment plants.

\section{CONCLUSIONS}

The industrial treatment with Chromated Copper Borate increased the Eucalyptus urophylla $\mathrm{x}$ Eucalyptus grandis wood resistance to white and brown-rot fungi.

The application of $1.5 \%$ Chromated Copper Borate concentration and 30 minutes of pressure in the autoclave can be applied in treating Eucalyptus urophylla $\mathrm{x}$ Eucalyptus grandis wood without compromising its resistance to attack by Trametes versicolor and Gloeophyllum trabeum fungi.

\section{ACKNOWLEDGEMENTS}

The authors would like to thank Arocan company for funding.

\section{SUBMISSION STATUS}

Received: 30 Mar. 2018

Accepted: 09 Apr. 2019

Associate editor: Edy Eime Baraúna

(1) 0000-0001-5239-9592

\section{CORRESPONDENCE TO}

\section{Carlos Roberto Sette Jr}

Universidade Federal de Goiás, Escola de Agronomia, Goiânia, GO, Brasil

e-mail: crsettejr@hotmail.com

\section{REFERENCES}

Associação Brasileira de Preservadores de Madeira - ABPM. [cited 2018 jan. 29]. Available from: http://www.abpm.com.br/faq.

Amaral LS, Silva JRM, Hein PRG, Trugilho PF. Influência do diâmetro e umidade no tratamento preservativo demoirões de Eucalyptus. Revista Árvore, 2014; 38(5): 919-925.

American Society for Testing and Materials. ASTM D-2017: standard method of accelerated laboratory test of natural decay resistance of woods. Annual Book of ASTM Standards, West Conshohocken, 2005. 5p. 
American Society for Testing and Materials. ASTM D-1413: standard test method for wood preservatives by laboratory soil-block cultures. Annual Book of ASTM Standards, Philadelphia, 2007. 8p.

Carvalho DE,Santini EJ, Gouveia FN, Rocha MP. Resistência natural de quatro espécies florestais submetidas a ensaio com fungos apodrecedores. Floresta e Ambiente, 2015; 22(2): 271-276.

Costa MA, Costa AF, Pastore TCM, BragaJWB, Gonçalez JC. Caracterização do ataque de fungos apodrecedores de madeiras através da colorimetria e da espectroscopia de infravermelho. Ciência Florestal, 2011; 21(3): 567-577.

Gallio E,Gatto DA, Lazarotto M,Beltrame R. Eficiência de preservantes fungicidas em madeiras de duas espécies florestais submetidas à deterioração por fungo. Nativa, 2017; 5(6): 434-439.

Indústria Brasileira De Árvores - IBÁ (2018). Relatório anual. [cited 2018 dez. 08]. Available from: https:/www.iba.org/datafiles/ publicacoes/relatorios/digital-sumarioexecutivo-2018.pdf.

Kelley SS, Jellison J, Goodell B. Use of NIR and pyrolysis-MBMS coupled with multivariate analysis for detecting the chemical changes associated with brown-rot biodegradation of spruce wood. FEMS Microbiology Letters, 2002; 209(1): 107- 111.

Lazarotto M, Cava SS, Beltrame R, Gatto DA, Missio AL, Gomes LG et al. Resistência biológica e colorimetria da madeira termorretificada de duas espécies de eucalipto. Revista Árvore, 2016; 40(1): 135-145.

Lelis AT, Brazolin S, Fernandes JLG, Lopez GAC, Monteiro MBB, Zenid GJ. Biodeterioração de madeiras em edificações. São Paulo: Instituto de Pesquisas Tecnológicas; 2001.

Lepage ES. Preservativos e sistemas preservativos. 1st ed. São Paulo: Instituto de Pesquisas Tecnológicas; 1986.

Lopes DJV, Paes JB, Jankowsky IP, Segundinho PGA, Vidaurre GB. Influências do diâmetro e umidade da madeira na qualidade do tratamento preservativo. Floresta e Ambiente, 2017; 24(s/n.): 10p.

Oliveira BRU, LatorracaJVF, Tomazello Filho M, Palermo GPM, Carvalho AM, Pastro MS. Microdensitometria de raios X aplicada na determinação da variação da densidade do lenho de árvores de Eucalyptus grandis W. Hill. Scientia Forestalis, 2012; 40(93): 103-112.

Oliveira JTS, Paes JB, Vidaurre GB. Resistência biológica da madeira de espécies de eucalipto ao ataque de cupim de madeira seca. Scientia Forestalis, 2017; 45(113): 145-150.
Paes JB, Medeiros Neto PN, Lima CR, Freitas MF, Diniz CE. Efeitos dos extrativos e cinzas na resistência natural de quatro madeiras a cupins xilófagos. Cerne, 2013; 19(3): 399-405.

Paes JB, Melo RR, Lima CR. Resistência natural de sete madeiras a fungos e cupins xilófagos em condições de laboratório. Cerne, 2007; 13(2): 160-169.

Ramos IEC, Paes JB, Farias Sobrinho DW, Santos GJC. Eficiência do CCB na resistência da madeira de algaroba (Prosopis juliflora (Sw.) D.C.) em ensaio de apodrecimento acelerado. Revista Árvore, 2006; 30(5): 811-820.

Severo ETD, Calonego FW, Sansígolo CA, Bond B. Changes in the chemical composition and decay resistance of thermally-modified Hevea brasiliensis. Wood PloS One, 2016; 11(3): 1-10.

Silva LF, Paes JB, Jesus Júnior WC, Oliveira TS, Furtado EL, Alves FR. Deterioração da madeira de Eucalyptus spp. por fungos xilófagos. Cerne, 2014; 20(3): 393-400.

Torres A, Marcel P, Paes B, Lira Filho JA, Nascimento JWB. Tratamento preservativo da madeira juvenil de Eucalyptus camaldulensis Dehnh. pelo método de substituição de seiva. Cerne, 2011; 17(2): 275-282.

Valle MLA, Silva JC, Della Lucia RM, Evangelista WV. Retenção e penetração de CCA em madeira de primeira e segunda rotação de Eucalyptus urophylla S. T. Blake. Ciência Florestal, 2013; 23(2): 481-490.

Vidal JM, Evangelista WV, Silva JC, Jankowsky IP. Preservação de madeiras no Brasil: histórico, cenário atual e tendências. Ciência Florestal, 2015; 25(1): 257-271.

Vivian MA, Santini EJ, Modes KS, Morais WWC. Qualidade do tratamento preservativo em autoclave para a madeira de Eucalyptus grandis e Eucalyptus cloeziana. Scientia Forestalis, 2012; 40(96): 445-453.

Vivian MA, Santini EJ, Modes KS, Garlet A, Morais WWC. Resistência biológica da madeira tratada de Eucalyptus grandis e Eucalyptus cloeziana a fungos apodrecedores em ensaios de laboratório. Ciência Florestal, 2015; 25(1): 175-183.

Xuan L, Hui D, Cheng W, Wong AHH, Han G, Tan WK et al. Effect of preservative pretreatment on the biological durability of corn straw Fiber/HDPE Composites. [cited 2017 jul. 12]. Available from: https://www.mdpi.com/1996-1944/10/7/789/htm. 